\title{
Looking for Diversified Specialization in the Regions of Turkey
}

\author{
Türkiye Bölgelerinde Çeșitlenmiş Uzmanlaşmanın Incelenmesi
}

\author{
Ferhan GEZiCi KORTEN, ${ }^{1}$ Zeynep ELBURZ²
}

\section{ABSTRACT}

Different forces within the urban and regional dynamics made significant either localization economies or urbanization economies in different circumstances. Several researchers highlighted that diversity and specialization are not exact opposites; a region can be both diversified and specialized. Diversified cities might include several specialized clusters, as diversity might be having a healthy mix of sectoral employment. Studies mainly look at the relationship between the sectorial specialization/diversification and employment growth and productivity. From all that, the concept of diversified specialization has recently occurred related to the outcome of relationships between the sectors and against the economic shocks. Furthermore, decision makers generally prefer a diverse specialization rather than just one or a few. The aim of this paper is to explore the specialization, diversification due to the manufacturing activities and furthermore diversified-specialization pattern of the 26 NUTS 2 regions of Turkey between 2009 and 2014. How the regions specialize and indicate diversification of related industries, and if they point out different patterns regarding technology levels of the industries are the main research questions. Moreover, the performance of regions is explored by dynamic shift-share analysis whether there is a relationship between the specialization/diversification pattern of regions and their advantages.

Keywords: Diversified specialization; region; Turkey.

ÖZ

Kentsel ve bölgesel dinamikler içinde etkili olan güçler gerek yerelleşme ekonomilerini gerekse kentleşme ekonomilerini farklı koşullarda önemli hale getirmiştir. Çeşitli araştırmacılar, çeşitliliğin ve uzmanlaşmanın kesin karşıtık olmadığını vurgulamıştır; buna göre bir bölge hem çok sayıda sektör çeşitliliğine sahip olabilir hem de belirli sektörlerde uzmanlaşabilir. Sektörel çeşitlilik gösteren kent/bölgeler birden fazla uzmanlaşmış küme içerebilir ve sektörler arası ilişki nedeniyle sağlıklı bir yapı ortaya çıkarırlar. Önceki çalışmalar ağırlıklı olarak sektörel uzmanlaşma/çeşitlilik ile istihdam artışı ve verimlilik arasındaki ilişkiyi incelemektedir. Bu bağlamda, çeşitlenmiş uzmanlaşma kavramı son zamanlarda sektörler arasındaki ilişkiler ve ekonomik şoklara karşı önemli bir yaklaşım olarak ortaya çıkmıştır. Ayrıca, karar vericiler genellikle bir veya birkaç uzmanlaşmış sektörden çok çeşitlenmiş uzmanlığı tercih etmektedirler. Bu makalenin amacı, 2009-2014 yılları arasında Türkiye'nin 26 iBBS düzey 2 bölgesinin imalat faaliyetlerindeki uzmanlaşma, çeşitlilik ve çeşitlenmiş uzmanlaşma durumlarını keşfetmektir. Sektörel uzmanlaşma ve çeşitlilik ile bu sektörlerin teknoloji düzeyleri, bölgelerin ekonomik yapısına ilişkin bilgiyi sunarken farklı tipolojileri de ortaya çıkarmaktadır. Ayrıca bölgelerin çeşitlenmiş uzmanlaşma yapısı ile bölgelerin sahip olduğu avantajlar arasında ilişki olup olmadığı dinamik değişsim-pay analizi ile incelenmektedir.

Anahtar sözcükler: Çeşitlenmiş uzmanlaşma; bölge; Türkiye. 


\section{Introduction}

Following the studies on agglomeration economies, MAR and Jacobs externalities are still the benchmarks of different studies. ${ }^{1}$ Different forces within the urban and regional dynamics made significant either localization economies (Marshall, 1920) or urbanization economies (Jacobs, 1969) in different circumstances or cases. As Hoover (1937) described, localization economies are advantages of being in the same location of a single or related industry, while urbanization economies have the advantages of being together with different sectors. On the other hand, Duranton and Puga (2000) highlight that specialization is partly the result of economic interactions within a given sector, whereas diversity is fostered by economic interactions across sectors. The question is always interesting as to whether it is better for a region to be more specialized or to develop different industry concentrations (Cortright, 2006). Recently, the concept of diversified-specialization has become significant since diversified-specialized cities have the advantage of both MAR and Jacobs externalities. Furthermore, Frenken et al. (2007) emphasized that diversified specialized cities/ regions are not severely affected by sector-specific shocks, since they focus on relatively wider industry groups.

The aim of this paper is to explore the pattern of diversified-specialization of the manufacturing industry within the NUTS 2 regions of Turkey in the period of 2009 to 2014. The sectors are also analyzed based on their technology level in order to see if there has been a structural change. The paper aims to find out: how the regions' economy indicates specialization and/or diversification on manufacturing industry; and to what extent do regions indicate diversified specialization pattern having the advantage of both MAR and Jacobs externalities. We assume that first there is a relationship between the diversified specialization and employment growth; secondly that diversified specialized regions have more regional advantages as the base of manufacturing industry. Therefore, how the regions' employment change is related to the national growth, industry mix and regional advantages would be explored by the shift-share analysis. ${ }^{2}$ The analyses would provide us some insights about the region's structure and performance. To the best of our knowledge, this study is the first research to explore the concept of diversified specialization for Turkish regions with the post 2000 data.

The remainder of the paper is organized as follows. Section 2 provides an overview of the specialization/diversi-

\footnotetext{
Marshall-Arrow-Romer (MAR) externalities which formalized by Glaeser et al. (1992) from the studies Marshall (1920), Arrow (1962), and Romer (1986), assume intra-industry spillovers while Jacobs externalities (1969) argue inter-industry spillovers.

2 Shift-Share analysis is first developed by Dunn (1960) to investigate employment growth (decline) in a specific time and region (Barff and Prentice III, 1988).
}

fication and diversified specialization literature. Section 3.1 and Section 3.2 explain data and methodology while Section 4 presents the results of analysis. Finally, Section 5 concludes the research with further suggestions.

\section{Literature Review}

\section{Theoretical Background}

Discussion of specialization actually goes back to Ricardo's comparative advantage theory based on the abundance of factor endowments. Recently the new economic geography claims that improvement of the factor endowment in a region increases its attraction as location for other manufacturing activities and leads to a cumulative process (Krugman, 1998; Fujita et al., 1999). According to Rodrik (2013), as countries grow out of poverty, their economies become less specialized and more diversified. Since an economy has been growing, it has also been producing more in size, quality and variety (Grossman and Helpman, 1992). On the other hand, Imbs and Wacziarg (2003) point out that diversity is slowing down and there would be a trend for re-specialization, while the GDP per capita raises, therefore they mention about a U-curve trend for specialization and diversification of the economy. Studies, which are trying to explore the changes in regional specialization patterns, point to a decline of specialization in employment in the EU (Traistaru et al., 2002; Marelli, 2006). Specialization does not have the same meaning of concentration; however, it is related to agglomeration economies. A region is considered to be specialized if a small number of industries have a large combined share in the region's economy.

There have been several approaches and studies that look at the relationship between the sectorial specialization/diversification and employment growth, productivity and city size (Table 1). Emphasis is on the links between specialization and resources, the cities would be specialized on the sectors that are not dependent on the resources all the time (Rosenthal and Strange, 2006). Glaeser et al. (1992) found that specialization is negatively associated with growth in a particular industry, while Henderson (1997) found strong evidence of the importance of industry specialization. Moreover, his study in 2003 indicated that concentration of the same industry has a strong effect on productivity at the county level of the US. Brülhart (2001) reached evidence on increasing specialization in employment terms for Western Europe since 1970's. Duranton and Puga (2000) are interested in the city size and put forward that larger cities are more diversified, and diversity fosters employment growth by attracting new and innovative sectors, whereas specialization reduces growth. It has recently become more significant for the region's vulnerability when they face economic shocks. 
Table 1. An overview of the studies from the literature

\begin{tabular}{ll} 
Related topics with specialization/diversity & Studies from literature \\
\hline Changes on regional specialization & $\begin{array}{l}\text { Traistaru et al. (2002); Marelli (2006); O'Donoghue and Townshend (2005); Peker } \\
\text { (2012); Brülhart (2001) }\end{array}$ \\
Employment growth, productivity, city size & Glaeser et al. (1992); Henderson (1997); Duranton and Puga (2000); Beer and \\
& Clower (2009); Dewhurst and McCann (2007); Falcığlu (2008) \\
Regional economic resilience & Dissart (2003); Davies and Tonts (2010); Malizia and Ke (1993); Boschma and \\
& Gianelle (2014) \\
Innovation related variety smart specialization & Paci and Usai (2000); Fritsch and Slavtchev (2007); Boschma and Gianelle (2014); \\
& Duranton and Puga (2001); Falcığlu (2011); Boschma et al. (2012) \\
Diversified specialization & Duranton and Puga (2000); Malizia and Ke (1993); Nakamura and Paul (2009); \\
& Farhauer and Kröll (2012); Frenken et al. (2007); Cortright (2006)
\end{tabular}

However, there is common sense on diversification that it is good against the shocks; Kemeny and Storper (2012) reiterate that in a large diversified economy, the collapse of demand for an industry would have a large impact on the whole economy.

Frenken et al. (2007) also emphasize that a region specializing in a certain combination of related sectors is likely to experience higher growth rates than a region specializing in an unrelated portfolio. Moreover, they pointed out that related sectors often share the same technology and knowledge base, which is providing opportunity for innovation to the related sectors. There also have been studies looking at the relationship between sectorial specialization and innovation (Paci and Usai, 2000; Fritsch and Slavtchev, 2007). The concept of related variety by Boschma (2013) and Boschma et al. (2012) includes the premise that technological relatedness between sectors in a region enables knowledge spillovers and regions diversify into new industries that are similar to existing ones.

In economic geography, because of the still unresolved MAR versus Jacobs debate, how a region's sectoral structure shapes its economic development is still an interesting topic (Martin and Sunley, 2017). However, several researchers highlight that diversity and specialization are not exact opposites; a region can be both diversified and specialized. Diversified cities might include several specialized clusters (Duranton and Puga, 2000; Malizia and Ke, 1993; Nakamura and Paul, 2009), as diversity is considered to have a healthy mix of sectoral employment. From all these, it is really difficult to decide whether it is better for a region to be specialized or diversified, since the advantages or disadvantages would be related to complex systems of specific regions. Therefore, Duranton and Puga (2000) suggest that there will always be a need for both diversified and specialized cities/regions. But, decision makers generally prefer a diverse specialization rather than just one or a few (Cortright, 2006), while Farhauer and Kröll (2012) point out that the concept of diversified specialization would be an alternative to the cluster concept. Their findings point out that an increase in diversified specialization enhances Gross Value Added (GVA) per working hours. On the other hand, they indicate that employment growth is higher in cities focusing on more sectors than in cities specializing in only one sector. Moreover, Boschma (2013) suggests that regional policies should consider making regions diversify through relatedness.

The concept of diversified specialization has recently occurred (Frenken et al., 2004; Farhauer and Kröll, 2012) and has been proposed as a more appropriate chacaterization of the economic structure (Martin and Sunley, 2017). The firms have benefits from both MAR and Jacobs externalities as the advantage of diversified-specialized cities. In terms of size, diversified-specialized cities are generally smaller than diversified ones, and it is expected that diseconomies of agglomeration is relatively lower. On the other hand, they are not severely affected by sector-specific shocks, since they focus on relatively wider industry groups. According to Acemoglu (2002), against the influence of the globalization process on labor demand, diversified-specialized cities may show higher employment growth than others.

\section{Emprical Studies}

Specialization and diversification have been evaluated with various measures in the empirical literature. Specialization measures can be looked over in two categories: absolute (Herfindahl index, concentration ratio) and relative measures (Relative specialization index, GINI, Krugman index) each which has some advantages and disadvantages. Absolute measures are based on employment for the region in question (Dewhurst and McCann, 2002) and do not consider the distribution of employment of the other regions (Longhi et al., 2005). In contrast to absolute measures, relative measures take into account comparisons of the distribution of regional employment between sectors 
(Dewhurst and McCann, 2002). Absolute and relative measures are both important and useful measures for different aspects while some reach a conclusion that choice of measure might alter the outcome, e.g. Dewhurst and McCann (2002) and Amiti (1996) find that all the measures of specialization results are quite similar.

Suedekum (2007) uses the Krugman specialization index and locational GINI coefficient to measure regional specialization and geographical concentration of industries in Germany. He finds evidence neither for specialization nor for concentration process of industries for the time period between 1993 and 2001. For the case of Romanian regions, Ceapraz (2008) employs GINI and Herfindahl regional specialization index to analyze the economic structure with both relative and absolute measures. In Turkey, the studies on this issue mostly investigate the pattern of regional specialization and the data availability is mostly limited by the year 2000. The study of Falcıoğlu and Akgüngör (2008) points out that the manufacturing sector became more concentrated and the regions more specialized between the years of 1980 and 2000, while the findings of Falcıoglu (2008) put forward that regional specialization is not a significant determinant in productivity of Turkish regions. Furthermore, Falcıoğlu (2011) proves that regions between the year of 1995 and 2001, having a higher level of related variety were found to be more innovative while related variety was a determinant of productivity in the manufacturing industry. The study of Peker (2012) looks at the provinces of Turkey and all non-agricultural sectors between the years of 1990 and 2000 . The main findings underline the tendency toward more specialization and a negative relationship between the size and specialization of the provinces. Eser and Köse (2005) analyzed 44 provinces of Turkey in 2000 and emphasized that industries displayed more concentrated pattern when the value added and export rather than employment is taken into account. Moreover, the studies conclude that high technology sectors tend to concentrate more than low technology ones. More recently, Eraydın (2016) calculates diversity by using Herfindahl diversity index and specialization by Krugman's specialization index for manufacturing sector in 26 regions to reflect adaptive capacity of a region which is a part of determinants of resilience in the study.

Economic diversity has been attracting attention since 1930's (Dissart, 2003), but still there are several definitions of diversity and diversification terms, which induce confusion about its measures (Siegel et al., 1995). Imbs and Wacziarg (2003) use a variety of measures of sectoral concentration including GINI coefficient and the Herfindahl index to detect the stages of diversification for the countries from different development levels. O'Donoghue and Townshend (2005) investigate the changing employment structure in Britain by using GINI coefficient to detect diversification in 2001. Longhi et al. (2005) examine the relationship between unemployment and sectoral diversification by employing the Herfindahl index for NUTS 2 regions in the $\mathrm{EU}$ and their results suggest that regional diversification may reduce unemployment. For the concept of diversified-specialization, Farhauer and Kröll (2012) propose a diversified-specialization index which takes into account the cumulated share of the $x$ largest sectors in total region employment and defines a specialized mix of sectors for regions. They analyze the effects of diversified specialization on regional economic performance for the case Germany and conclude that there is a positive and significant link between these two variables.

This study is the first attempt to investigate diversified specialization of the manufacturing industry combine with regional performance in Turkey with the latest regional data.

\section{The Data and Methodology}

\section{Data}

In this empirical analysis, regional manufacturing employment data at the NUTS 2 level in the period of 2009 to 2014 have been used. The source of the employment data is TurkStat, Business and Annual Industry and Service Statistics (2008). ${ }^{3}$ Classification of economic activities for employment data is used based on NACE Rev. 2 (see in Appendix B). Additionally, the OECD Classification of Manufacturing Industries Based on Technology (2003) is used in the analysis for a better understanding of the NUTS 2 regions' economic structure since not only the level of specialization- diversification, but technology level of the sectors are significant for structural change (see in Appendix C). This classification divides manufacturing industries into high-technology, medium-high technology, medium-low technology and low technology sub-groups according to research and development (R\&D) intensities.

As it is pointed out in different studies, the results would differ with respect to the levels of sectoral disaggregation and different levels of geographical units. By taking into account that, this analysis is conducted based on 26 NUTS 2 regions and 24 manufacturing sectors in Turkey while other Turkish studies prefer to use spatial aggregation as geographical regions (Akgüngör et al., 2003; Akgüngör, 2006) and NUTS 3 regions (Kıymalıoğlu and Ayaoğlu, 2006; Peker, 2012).

\section{Methodology}

Specialization and diversification measures are employed in this paper to examine the patterns in manufac-

\footnotetext{
3 After 2002, TurkStat has released two-digit manufacturing employment data every year at the NUTS 2 level (see in Appendix A). Since the industry aggregation has been changed in 2009 , we used relatively limited time period.
} 
turing industry in the first stage of the related analyses.

First, to set how specialized a region is in an industry relative to its nation, the "relative specialization index" (RZI) by Duranton and Puga (2000) is employed. The Relative Specialization Index can be express as:

$$
R Z I_{i}=\max _{j}\left(s_{i j} / s_{j}\right)
$$

where sij is the share of industry $j$ in region $i$ and $s j$ is the share of industry $j$ in the national employment. Since both the level of specialization of the regions in a year and the changes of the level of specialization are essential to capture the whole regional specialization context, Relative Specialization Index and changes of that index between 2009 and 2014 are examined.

In order to calculate the differences in sectoral employment shares at the national level, the "Relative Diversity Index" (RDI) as applied by Duranton and Puga (2000), de Vor and de Groot (2010), and Farhauer and Kröll (2012) is used. The Relative Diversity Index (RDI) which can be express as:

$$
\mathrm{RDI}_{\mathrm{i}}=1 /\left|S_{i j} S_{\mathrm{j}}\right|
$$

is similar to the inverse of the Herfindahl index, and the great value of RDI indicates the more diversified region.

Furthermore, in order to see the diversified specialization pattern of the regions the approach of Farhauer and Kröll (2012) is followed. The formulation of the diversified specialization can be expressed as:

$$
A N T 5 G_{i}=\frac{E_{i j \max }+E_{i j \max -1}+E_{i j \max -2}+E_{i j \max -3}+E_{i j \max -4}}{E_{i}} * 100
$$

where, $A N T 5 G_{j}$ is the share of the five largest sectors in total regional employment, $E_{i j}$ is the employment in sector $j$ in region $i$ and $E_{i}$ is the total employment in region $i$.

As a second stage, a dynamic shift-share analysis is used to explore employment change and especially the advantages of the regions for manufacturing sector. Finally the analysis provides to find out the relationship between the performance (employment growth) of the regions and the specialization/diversification pattern. The shiftshare analysis defines the employment change with three components (Merrifield, 1983). The national share (NS) is the change of the regional employment that could have taken place if regional employment had changed at the same rate as the national economy (Mayor et al. 2007). The industry mix (IM) component measures proportional shift due to a difference in industry growth between the region and the nation (Stimson et al., 2006). A region that contains a relatively large share of industries that are fast (slow) growing nationally will have a positive (negative) industry mix effect (Dinç et al., 2003). The regional shift, or regional share, (RS) component measures the differ- ences between regional and national industry growth rate caused by local factors (Mitchell et al. 2007). Therefore it is possible to explore the advantages or disadvantages of the regions by evaluating the results of shift-share analysis (Dinç, 2002). Although traditional shift-share analysis is useful and preferable among researchers, it only captures the changes between beginning and terminal year, ignoring the changes during the period. Following Barff and Prentice III (1988), the dynamic shift-share analysis is used to track the complete evolution of the employment changes in the regions. The formula of the dynamic shiftshare analysis;

$$
\begin{gathered}
e_{i}^{t+n}-e_{i}^{t}=N S_{i}+I M_{i}+R S_{i} \\
N S_{i}=\sum_{k=t+1}^{t+n}\left[e_{i}^{k-1}\left(G^{k}\right)\right] \\
I M_{i}=\sum_{k=t+1}^{t+n}\left[e_{i}^{k-1}\left(G_{i}^{k}-G^{k}\right)\right] \\
R S_{i}=\sum_{k=t+1}^{t+n}\left[e_{i}^{k-1}\left(g_{i}^{k}-G^{k}\right)\right]
\end{gathered}
$$

where $e_{i}, G^{k}, G_{i}^{k}, g_{i}^{k}, t, t+n$ denote respectively regional employment in $\mathrm{i}^{\text {th }}$ sector, growth rate of national total employment, growth rate of $\mathrm{i}^{\text {th }}$ sector employment for the nation, growth rate of $\mathrm{i}^{\text {th }}$ sector employment for a region, initial year of period, final year of period.

\section{Facts of Manufacturing Sector and Results of the Analyses}

Turkey has been defined as one of the emerging economies in the world in 2000s, however the distribution of growing Gross Domestic Product (GDP) has indicated a significant differentiation among the regions and people, since $25 \%$ of the total population got $53 \%$ of income in 2016. Regarding the structure of the economy, the manufacturing industry has long been the main GDP contributor in Turkey. However, the share of the sector did not display a significant change; its share was $22.1 \%$ in 2002 , while it was $24.2 \%$ in 2014 . The most striking increase occurred in the financial sector: while it was $8.9 \%$ in 2002 , it reached $13.2 \%$ in 2014 . The share of five important sectors in the Turkish economy (manufacturing, financial, wholesale trade, transportation and construction), increased from $59.5 \%$ to $68.2 \%$. In addition to this, growth rate of the sectoral shares in GDP between 2000 and 2014 shows that manufacturing sector's growth rate $(4.5 \%)$ is very close to total sectoral growth rate (4.4\%) while it is $7.9 \%$ for financial sector. Also, manufacturing industry employment growth and export indicators would be helpful to under- 
Table 2. Facts and figures on manufacturing sector

\begin{tabular}{ccccc}
\hline & $\begin{array}{c}\text { Unemployment } \\
(\%)\end{array}$ & $\begin{array}{c}\text { Share of manufacturing } \\
\text { export (\%) }\end{array}$ & $\begin{array}{c}\text { Share of manufacturing } \\
\text { employment (\%) }\end{array}$ & $\begin{array}{c}\text { Share of manufacturing } \\
\text { in GDP (\%) }\end{array}$ \\
\hline 2000 & 6,5 & 91,9 & - & 23,2 \\
2001 & 8,4 & 92 & - & 22,8 \\
2002 & 10,3 & 93,5 & 32,5 & 22,1 \\
2003 & 10,5 & 93,9 & 31,7 & 22,7 \\
2004 & 10,8 & 94,3 & 28,7 & 23,2 \\
2005 & 10,6 & 93,7 & 28,3 & 23,2 \\
2006 & 10,2 & 93,8 & 28,1 & 23,7 \\
2007 & 10,3 & 94,2 & 28,2 & 23,6 \\
2008 & 11 & 94,8 & 27,1 & 23 \\
2009 & 14 & 93,4 & 27,9 & 23,9 \\
2010 & 11,9 & 92,6 & 27,3 & 24,2 \\
2011 & 9,8 & 93,4 & 27,2 & 24,1 \\
2012 & 9,2 & 93,9 & 27,0 & 24,0 \\
2013 & 9,7 & 93,1 & 26,6 & \\
2014 & 9,9 & 93,3 & & \\
\hline
\end{tabular}

Source: TurkStat, 2015.

Table 3. Manufacturing sector employment and export change according to OECD classification

\begin{tabular}{|c|c|c|c|c|c|c|}
\hline & & Low & Medium low & Medium high & High & \\
\hline \multirow[t]{3}{*}{ Export } & Growth rate (2003-2014) & 0,08 & 0,13 & 0,12 & 0,04 & \\
\hline & Share (\%) 2003 & 44,9 & 21,6 & 28,7 & 4,8 & 100 \\
\hline & Share (\%) 2014 & 35,8 & 28,3 & 33,7 & 2,2 & 100 \\
\hline \multirow[t]{3}{*}{ Employment } & Growth rate (2003-2014) & 0,03 & 0,07 & 0,04 & 0,06 & \\
\hline & Share (\%) 2003 & 61,6 & 19,5 & 17,4 & 1,5 & 100 \\
\hline & Share (\%) 2014 & 53,5 & 27,3 & 17,5 & 1,7 & 100 \\
\hline
\end{tabular}

Source: TurkStat, 2015; Ministry of Economy, 2015.

stand the structure of the national economy and how the sectors are changing during the time period (Table 2).

Although the low technology sectors are still the main employment generators, it has been an increasing trend in the export values of medium-low and medium-high technology sectors in Turkey. The share of employment in high-technology sectors within total manufacturing was only $1,70 \%$, while the share of export was 2,20\% in 2014 (Table 3). Gönenç et al. (2012) point out that the growth of hightech industries appears to have accelerated in the 2000s due to the skilled labor force of western regions.

The facts and figures above motivate us to examine the regional implications of the economy with respect to specialization and diversification of the manufacturing sector. Although the manufacturing sector has made a significant contribution to the national economy, fast growing sectors especially in the metropolitan regions have become the engine of national economic growth in the last two decades.

\section{Specialization and Diversity}

According to 2014 manufacturing specialization index results, Eastern regions indicate a low specialization pattern except for TRC1 Gaziantep. On the other hand, TR10 Istanbul, TR62 Adana and TR61 Antalya among the most developed regions of Turkey, have a low level of manufacturing specialization. TR81 Zonguldak indicates the highest manufacturing specialization as an outlier in 2009, since the region is dependent on the resource base and heavy industrial activities. The dominance of the Marmara region (TR41 Bursa, TR21Tekirdağ, TR42 Kocaeli) on the production of the country is obvious. In addition to this, TR72 Kayseri and TR63 Hatay are relatively high specialized regions in the Anatolia, while TR31 Izmir and TR82 Kastamonu are the regions which have the highest positive change in terms of specialization between 2009 and 2014 (Fig. 1).

According to the diversification index analysis, the region which had the highest diversified manufacturing 


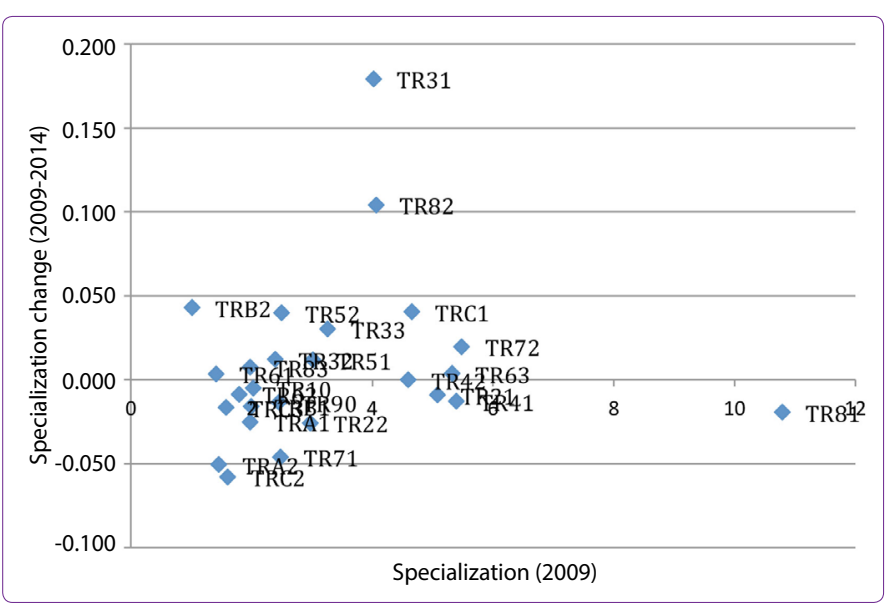

Figure 1. The level and change of manufacturing specialization of the regions.

economy in 2014 is TR62 Adana, while TR81 Zonguldak and TR62 Adana indicate the highest increase as well (Fig. 2). However, 11 regions became less diversified during the analyzed period, while TR31 Izmir as the highest diversified region in 2009 had diminishing diversification.

Low-technology industry mostly displays more dispersed pattern, while high technology ones are highly concentrated (Figure 3). Although the Marmara region as the main industrial zone and the most developed part of the country is the home of high technology industry, TR52 Konya and TR62 Adana show being specialized on medium-high technology sectors in 2014. However, TR10 Istanbul is no longer specialized in the manufacturing industry, the most specialized manufacturing industries were high technology ones. On the contrary, TRC1 Gaziantep, TR72 Kayseri and TR82 Kastamonu regions had a relatively high level of manufacturing specialization, and those industries were mainly low technology ones (see Fig. 3).

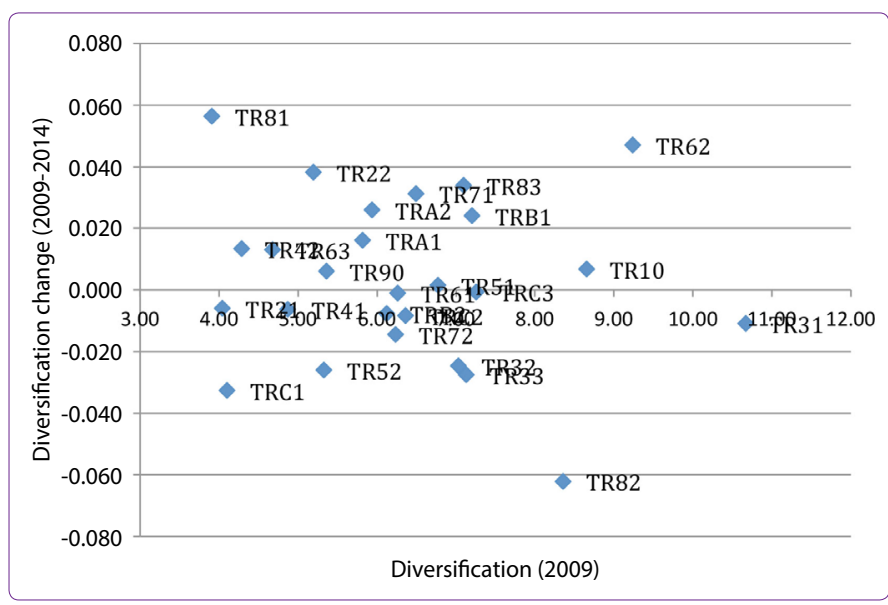

Figure 2. The level and change of manufacturing diversification of the regions.

Looking for diversified specialization, we accepted that specialization in five sectors generates stronger growth impulses than specialization in three sectors as Farhauer and Kröll (2012) pointed out. According to the diversified specialization results based on cumulated share of the 5 largest sectors in the region (ANT5), the first ten regions are the main manufacturing bases of Turkey. These regions have a diversified specialization value between 31.7 and 18.8 in 2009, and 32,3 and 20,7 in 2014. On the other hand, metropolitan regions, tourism destinations in the southwest and less developed eastern provinces indicate diversified specialization values below the mean (Table 4).

13 regions (TR33 Manisa, TR52 Konya, TR61 Antalya, TR31 Izmir, TR62 Adana, TR63 Hatay, TR72 Kayseri, TR82 Kastamonu, TRC1 Gaziantep, TR21 Tekirdağ, TRB1 Malatya, TRC3 Mardin, TRB2 Van) indicate an increasing trend on diversified specialization (Table 4). However, the rising stars of analysed period are especially TR62 Adana and

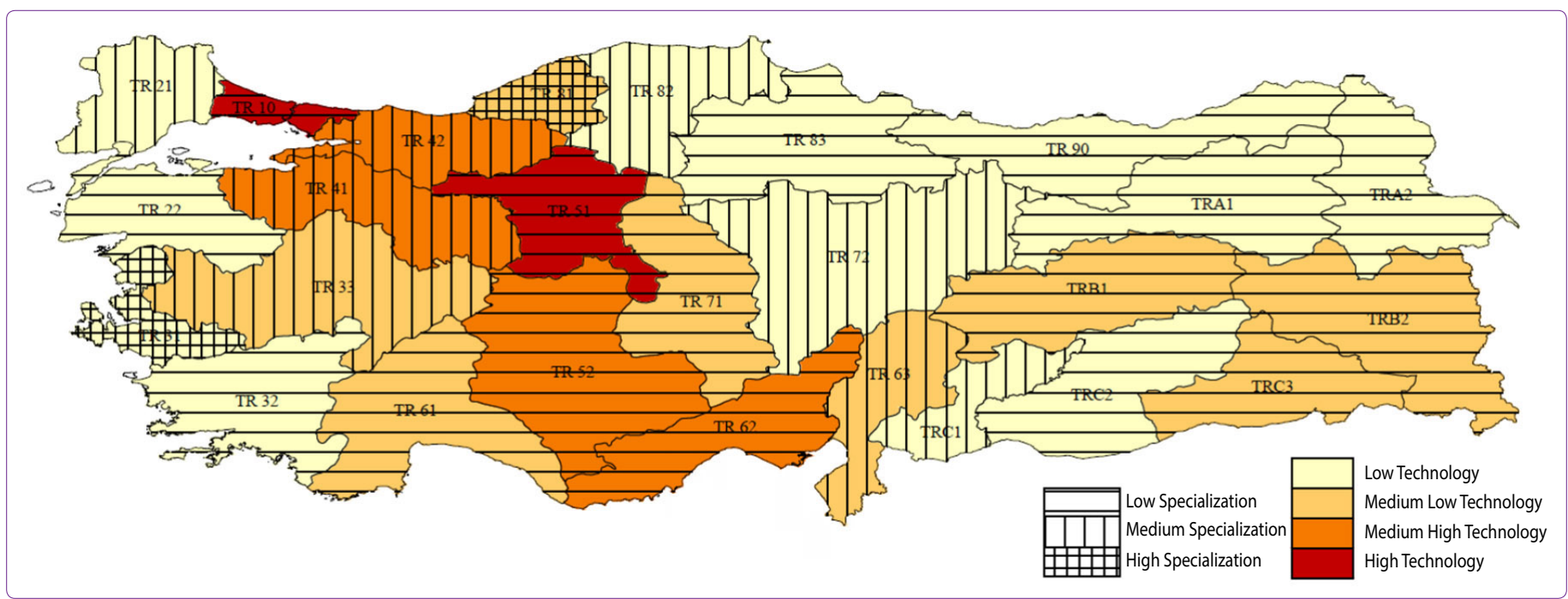

Figure 3. The level of specialization and technology classification of sectors (2014). 
Table 4. Diversified Specialization and Regional Performance (Employment Growth and Positive Regional Shift)

\begin{tabular}{|c|c|c|c|c|}
\hline & $\begin{array}{c}\text { Diversified Specialization } \\
\text { (ANT5- 2009) }\end{array}$ & $\begin{array}{l}\text { Diversified Specialization } \\
\text { (ANT5- 2014) }\end{array}$ & $\begin{array}{c}\text { Employment Growth } \\
(2009-2014)\end{array}$ & $\begin{array}{l}\text { Regional Shift } \\
(2009-2014)\end{array}$ \\
\hline TR21 Tekirdağ & 31,7 & 32,3 & 60.854 & 18.023 \\
\hline TR41 Bursa & 27,4 & 26,7 & 108.133 & 7.827 \\
\hline TRC1 Gaziantep & 27,3 & 30,1 & 49.299 & 18.663 \\
\hline TR81 Zonguldak & 24,2 & 20,3 & 1.424 & -11.613 \\
\hline TR42 Kocaeli & 23,4 & 21,5 & 86.411 & 6.898 \\
\hline TR32 Aydın & 20,8 & 20,7 & 39.194 & 656 \\
\hline TR52 Konya & 20,0 & 22,9 & 36.790 & 9.954 \\
\hline TR63 Hatay & 19,9 & 22,2 & 34.105 & 7.163 \\
\hline TR72 Kayseri & 19,7 & 20,8 & 30.847 & 2.283 \\
\hline TR33 Manisa & 18,8 & 22,0 & 62.847 & 22.934 \\
\hline TR71 Kırıkkale & 17,8 & 15,2 & 9.086 & -2.404 \\
\hline TRB1 Malatya & 16,2 & 16,5 & 8.196 & -2.573 \\
\hline TR10 İstanbul & 15,7 & 14,6 & 227.567 & -92.394 \\
\hline TR82 Kastamonu & 15,5 & 21,9 & 10.121 & 3.354 \\
\hline TR31 İzmir & 15,4 & 16,5 & 73.966 & 1.854 \\
\hline TR22 Balıkesir & 15,1 & 14,2 & 11.714 & -3.990 \\
\hline TR83 Samsun & 14,7 & 14,7 & 14.406 & -5.079 \\
\hline TR90 Trabzon & 14,2 & 13,8 & 9.536 & -7.917 \\
\hline TRA1 Erzurum & 11,0 & 8,9 & 1.052 & -2.125 \\
\hline TR51 Ankara & 10,4 & 9,8 & 60.614 & 3.002 \\
\hline TR62 Adana & 9,3 & 11,7 & 37.979 & 9.669 \\
\hline TRC2 Şanlıurfa & 8,5 & 8,2 & 11.821 & 4.537 \\
\hline TRA2 Ağrı & 8,3 & 6,7 & 55 & -1.531 \\
\hline TRC3 Mardin & 8,0 & 9,7 & 7.653 & 3.946 \\
\hline TR61 Antalya & 7,2 & 8,1 & 27.971 & 8.027 \\
\hline TRB2 Van & 5,7 & 6,6 & 3.598 & 836 \\
\hline
\end{tabular}

Table 5. Regression results of employment growth (20092014) and diversified specialization (2009)

\begin{tabular}{lcc}
\hline Dep. Var: Employment growth & Coefficients & Sig. \\
\hline Constant & $-6060,4$ & 0,650 \\
& $(-0,46)$ & \\
Diversified Specialization (AN5-2009) & $2312,6^{* * *}$ & 0,005 \\
& $(3,12)$ & \\
$\mathrm{R}^{2}=0,30$ & & \\
\hline
\end{tabular}

Note: $\mathrm{t}$ statistics in parentheses.

TR52 Konya, not only regarding the specialization of the manufacturing industry but also increasing concentration of medium-high technology sectors. TR10 Istanbul, TR21 Tekirdağ, TR31 Izmir, TR33 Manisa, TR41 Bursa, TR42 Kocaeli, TR51 Ankara, TR52 Konya, TR61 Antalya and TR62 Adana are the regions that indicate more than one sector specialization of high and medium-high tech sectors.

To test our first assumption on a relationship between diversified specialization and manufacturing employment growth, we used Ordinary Least Squares (OLS) estimation which is a statistical method of linear regression. We defined manufacturing employment change as a dependent variable and estimated with an independent variable which is diversified specialization in 2009. A significant relationship between the diversified specialization of the regions and employment growth is obtained when Istanbul is excluded as an outlier of the model (Table 5). Therefore, our result proves the hypothesis that diversified specialized regions indicate higher employment growth.

The highest absolute employment change is seen in Istanbul as a fact of its high population, although the share of manufacturing employment and specialization has obviously declined. The first three regions (TR21 Tekirdağ, TRC1 Gaziantep, TR41 Bursa) did not change their position regarding diversified specialization from 2009 to 2014, while manufacturing employment growth in TR41 Bursa was higher as the medium-high technology specialized region (Table 4). 
Table 6. Classification of regions based on their regional advantage

\section{Regional Shift}

(2009-2014)

$(+)$

$(-)$

\begin{tabular}{|c|c|c|c|}
\hline Diversified & $(+)$ & TR21 Tekirdağ & TR81 Zonguldak \\
\hline Specialization & & TR32 Aydın & \\
\hline \multirow[t]{16}{*}{ (2014) } & & TR33 Manisa & \\
\hline & & TR41 Bursa & \\
\hline & & TR42 Kocaeli & \\
\hline & & TR52 Konya & \\
\hline & & TR63 Hatay & \\
\hline & & TR72 Kayseri & \\
\hline & & TR82 Kastamonu & \\
\hline & & TRC1 Gaziantep & \\
\hline & $(-)$ & TR51 Ankara & TR10 Istanbul \\
\hline & & TRC2 Şanlıurfa & TR22 Balıkesir \\
\hline & & TR31 Izmir & TR71 Kırıkkale \\
\hline & & TR61 Antalya & TR83 Samsun \\
\hline & & TR62 Adana & TR90 Trabzon \\
\hline & & TRB2 Van & TRA1 Erzurum \\
\hline & & TRC3 Mardin & TRA2 Ağrı \\
\hline & & & TRB1 Malaty \\
\hline
\end{tabular}

\section{Shift-Share Analysis}

Expectations from the regions that indicate more diversified specialization are higher employment and productivity growth to be less vulnerable against the sector-specific shocks. Therefore, dynamic shift-share analysis is a useful tool not only to find out the employment growth of the regions, but also to explore the different causes of em-

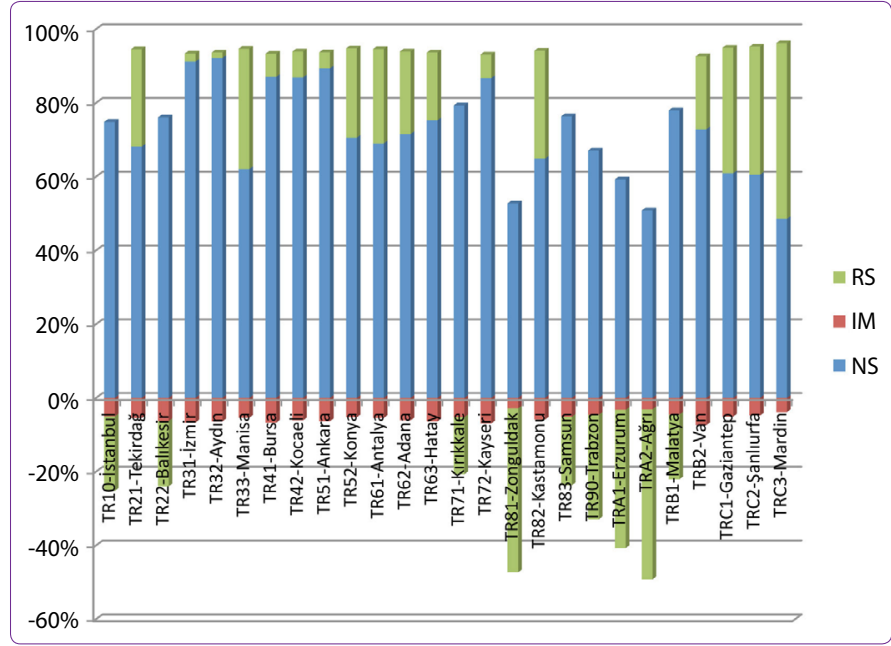

Figure 4. Contribution of three components of shift-share analysis.

ployment growth. First, we analyzed the impact of three different components on employment growth in 26 NUTS 2 regions between 2009 and 2014. Secondly, we focused on a regional component to identify the regions' economic strengths.

The results of the dynamic shift-share analysis point out that employment growth is based on national growth for all regions; however, the manufacturing sector has negative impact on employment growth (Fig. 4). Regional shift indicates different typologies; some regions indicate a positive regional shift, meaning that they have more advantage based on manufacturing activities; whereas the others indicate a negative regional shift.

Therefore the classification of the regions due to the regional shift and diversified specialization pattern would provide some regional typologies (Table 6 and Fig. 5). Seventeen regions have a positive regional shift and ten

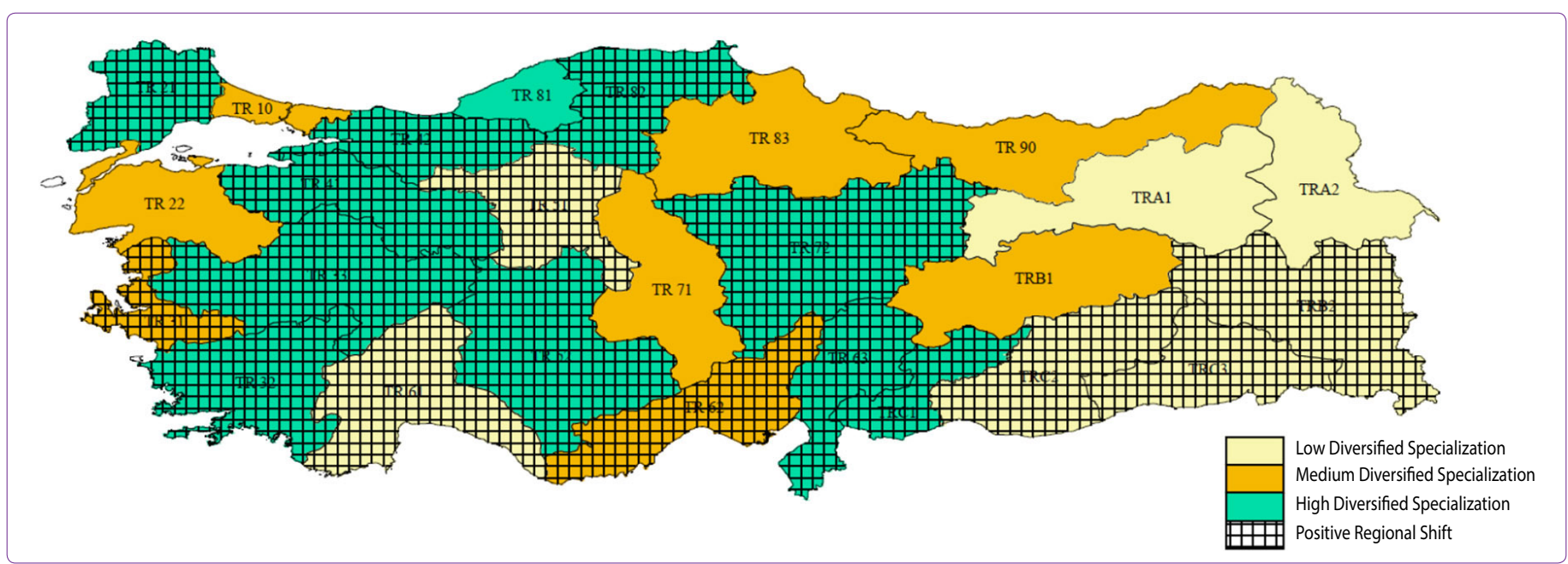

Figure 5. Classification of diversified specialization and regional shift. ${ }^{4}$

\footnotetext{
4 We used Jenks Natural Breaks (Jenks 1967) to classify data.
} 
of them indicate diversified specialization above the mean (Table 6). A positive regional shift indicates that the manufacturing sector has been growing faster in those regions than the national manufacturing growth. The highest values of regional shift occurred in the regions TR33 Manisa, TRC1 Gaziantep, TR21 Tekirdağ, TR52 Konya and TR62 Adana pointed out their regional advatages. On the contrary, TR10 Istanbul and TR81 Zonguldak are the regions that have no longer advantages for manufacturing industry. Most of the common characteristics of regions which indicate relatively high specialized diversification of the manufacturing sector and economic performance, having the advantages of being neighbors of metropolitan regions and having accessibility to the larger market not only in the west but also in the eastern part of Turkey (Figure 5). Furthermore, the western regions are increasingly specialized on high and medium high technology sectors.

\section{Conclusion}

In the literature, there have been several studies which explore whether the regions have become more specialized or more diversified. However, there is not any certain conclusion that either specialization or diversity is much better for all the regions.

The aim of this paper is not only to explore the pattern of specialization and diversity of the regions based on manufacturing employment, but to bring forward the concept of diversified specialization regarding the recent literature. There has been a strong argument on the advantages of diversified specialization making the regions get benefits of both localization and urbanization economies (Farhauer and Kröll, 2012; Boschma, 2013). Therefore, it is expected that if the regions become more diversified with their related specialized sectors, they would indicate employment growth. As Neffke et al. (2011) points out that when the region diversifies, this is rooted in their existing industrial profile, and the presence of related industries is more attractive for the new industries and jobs.

Although, high technology sectors mainly concentrate on the western regions in Turkey, there has been more dispersed manufacturing geography in the post 2000 era. Metropolitan regions have been transforming and specializing in high-technology sectors, whereas Izmir and Adana, as the main ports and most diversified structures, would have also created attractive hinterlands for manufacturing activities. The performance of east-south nodes (Gaziantep-Hatay) and new manufacturing specialization regions (Manisa-Konya-Kastamonu) should be analyzed to explore the determinants of their performance.

The relationship between the diversified specialization of the regions and employment growth also proves the hypothesis within the literature. The findings of the analysis display different regional typologies due to the employment growth, regional advantage, specialization/diversification and technology level of sectors in Turkey. Most of the highly diversified specialized regions indicate a positive regional shift and they have regional advantages for the manufacturing sector. However, some of the regions which have positive regional advantage do not indicate highly diversified specialization. Therefore, further studies would be to explore the factors of regional advantages such as the role of policies, determinants of agglomerations economies, and entrepreneurship capacity. Moreover, the concept of diversified specialization should be considered for the studies on regional economy through the relatedness of sectors.

\section{References}

Acemoglu, D. (2002) "Technical change, inequality, and the labor market", Journal of Economic Literature, 40(1):7-72.

Akgüngör, S. (2006) "Geographic concentrations in Turkey's manufacturing industry: identifying regional highpoint clusters", European Planning Studies, 14 (2):169-197.

Akgüngör, S., Kumral, N., Lenger, A. (2003) "National industry clusters and regional specializations in Turkey", European Planning Studies, 11 (6):647-669.

Amiti, M. (1996) "International trade in the manufacturing sectors of industrialised countries: Theory and Evidence". Dissertation in Economics, LSE, Chapter 3.

Arrow, K.J. (1962) "The Economic Implications of Learning by Doing". Review of Economic Studies 29:155-172.

Asheim, B., Boschma, R., Cooke, P. (2011) "Constructing regional advantage: platforms policies based on related variety and differentiated knowledge bases", Regional Studies, 45(7):893-904.

Barff, R. A., Prentice III, L. K. (1988) "Dynamic shift-share analysis". Growth and Change, 19(2):1-10.

Beer, A., Clower, T. (2009) "Specialisation and growth: evidence from Australia's regional cities", Urban Studies, 46(2):369389.

Boschma, R. (2013) "Constructing regional advantage and smart specialization: comparison of two European policy concepts", Papers in Evolutionary Economşc Geography, 13.12, Utrecht University.

Boschma, R., Giannelle, C. (2014) "Regional branching and smart specialisation policy", S3 Policy Brief Series No. 06/2014.

Boschma, R., Minondo, A., Navarro, M. (2012) "Related variety and regional growth in Spain", Papers in Regional Science, 91(2):241-256.

Ceapraz, I. L. (2008) "The concepts of specialisation and spatial concentration and the process of economic integration: theoretical relevance and statistical measures. The case of Romania's regions". Romanian Journal of Regional Science, 2(1):68-93.

Brülhart, M. (2001) "Growing alike or growing apart? Industrial specialization of EU countries". In: Wyplosz, (ed). The impact of EMU on europe and the developing countries. Oxford University Press.

Cortright, J. (2006) “Making sense of clusters: regional compet- 
itiveness and economic development, metropolitan policy program", Discussion Paper, The Brookings Institution.

Davies, A., Tonts, M. A. (2010) "Economic diversity and regional socioeconomic performance: an empirical analysis of the Western Australian grainbelt", Geographical Research, 48(3):223-234.

deVor, F., deGroot, H. (2010) "Agglomeration externalities and localized employment growth: the performance of industrial sites in Amsterdam", The Annals of Regional Science, 44(3)409-431.

Dewhurst, J. H., McCann, P. (2007) "Specialization and regional size". In:Fingleton B, (ed) New Directions in Economic Geography (pp. 204-229). Cheltenham: Edward Elgar.

Dewhurst, J.H., McCann, P. (2002) "A comparison of measures of industrial specialization for travel-to-work areas in Great Britain, 1981-1997", Regional Studies, 36(5):541-551.

Dinç, M. (2002) "Regional and local economic analysis tools", The World Bank, Washington DC.

Dinc, M., Haynes, K. E., Tarimcilar, M. (2003) "Integrating models for regional development decisions: A policy perspective", The Annals of Regional Science, 37(1):31-53.

Dissart JC (2003) "Regional economic diversity and regional economic stability: research results and agenda", International Regional Science Review 26(4):423.

Dunn, E. S. (1960) "A statistical and analytical technique for regional analysis", Papers in Regional Science, 6(1):97-112.

Duranton, G., Puga, D. (2000) "Diversity and specialisation in cities: why, where and when does it matter?", Urban Studies, 37 (3):533-555.

Duranton, G., Puga, D. (2001) "Nursery cities: urban diversity, process innovation, and the life cycle of products", American Economic Review, 91.5, 1454-1477.

Eser, U., Köse, S. (2005) “Endüstriyel Yerelleşme ve Yoğunlaşma Açısından Türkiye Sanayii: II İmalat Sanayiilerinin Analizi. Ankara Üniversitesi", SBF Dergisi, 60(2)(in Turkish).

Falcıoğlu, P. (2008) "Spatial determinants of regional productivity in Turkish manufacturing industry: an analysis for the regions of Turkey", Regional Studies Association International Conference, May 20-22. Prague.

Falcıoğlu, P. (2011) "The relation between geographical place and innovativeness: the case of Turkey", International Journal of Emerging and Transition Economies, 4(1-2):75-95.

Falcıoğlu, P., Akgüngör, S. (2008) "Regional specialization and industrial concentration patterns in the Turkish manufacturing industry: an assessment for the 1980-2000 period", European Planning Studies, 16(2):303-323.

Farhauer, O., Kröll, A. (2012) "Diversified specialisation-going one step beyond regional economics' specialization-diversification concept", Jahrbuch Für Regionalwissenschaft, 32(1):63-84.

Frenken, K., Van Oort, F., Verburg, T. (2007) "Related variety, unrelated variety and regional economic growth", Regional studies, 41(5):685-697.

Frenken, K., Van Oort, F., Verburg, T., Boschma, R. (2004) "Variety and regional economic growth in the Netherlands", Report to the Ministry of Economic Affairs.

Fritsch, M., Slavtchev, V. (2007) "Industry Specialization, Diversity and Efficiency of Regional Innovation Systems", Jena Eco- nomic Research Papers, 2007-018, www.jenacon.de.

Fujita, M., Krugman, P., Venables, A. J. (1999) "The spatial economy: cities, regions and international trade", Cambridge, Mass: MIT Press.

Glaeser, E., Kallal, H., Scheinkman, J., Schleifer, A. (1992) “Growth in cities", Journal of Political Economy, 100(6):1126-1152.

Gönenc, R., Röhn, O., Koen, V., Saygıll, Ş. (2012) "Structural reforms to boost Turkey's long-term growth", OECD Economics Department Working Papers, No. 987, OECD.

Grossman, G. M., Helpman, E. (1992) "Protection for sale”, National Bureau of Economic Research, No. w4149.

Henderson, J. V. (1997) "Externalities and industrial development", Journal of Urban Economics, 42(3):449-470.

Hoover, E. (1937) "Location theory and the shoe leather industry", Harvard University Press, Cambridge.

Imbs, J., Wacziarg, R. (2003) "Stages of diversification", American Economic Review, Vol. 93, No. 1, pp. 63-86.

Jacobs, J. (1969) "The economy of cities", NewYork: Random House.

Jenks, G. F. (1967) "The data model concept in statistical mapping", International Yearbook of Cartography 7:186-190.

Kemeny, T., Storper, M. (2012) "The sources of urban development: wages, housing and amenity gaps across American cities", Journal of Regional Science, 52(1).

Kıymalığlu, Ü., Ayoğlu, D. (2006) "Türk imalat sanayindeyığılma ekonomileri", Doğuş Üniversitesi Dergisi, 7 (2), 198-209 (in Turkish).

Krugman, P. (1998) "What's new about the new economic geography?" Oxford Review of Economic Policy, 14, 7-17.

Longhi, S., Nijkamp, P., Traistaru, I. (2005) "Is sectoral diversification a solution to unemployment? Evidence from EU regions", Kyklos, 58(4):591-610.

Malizia, E.E., Ke, S. (1993) "The influence of economic diversity on unemployment and stability", Journal of Regional Science, 33 (2):221-235.

Marelli, E. (2006) "Specialization and convergence of European regions", The European Journal of Comparative Economics, 4(2):149-178.

Marshall, A. (1920) "Principles of economics", London: Macmillan.

Mayor, M., Jesús López, A., Pérez, R. (2007) “Forecasting regional employment with shift-share and arima modeling", Regional Studies, 41(4):543-551.

Merrifield, J. (1983). The role of shift-share in regional analysis. Regional Science Perspectives, 13(1):48-54.

Ministry of Economy (2014) http://www.ekonomi.gov.tr/index. cfm?sayfa=7173D4A4-D8D3-8566-452001910DD1747A. Accessed 1 June 2014.

Mitchell, W., Myers, J., Juniper, J. (2007) “Extending shift-share analysis to account for spatial effects: A study using Australian census data". In Proceedings of the ARCRNSISS Methodology, Tools and Techniques and Spatial Theory Paradigm Forums Workshop, University of Newcastle, Australia, 15-17 June 2005 (p. 116). RMIT Publishing.

Nakamura, R., Paul, C.J. (2009) "Measuring agglomeration". In: Capello R, Nijkamp P, (ed). Handbook of regional growth and development theories (pp. 305-328). Cheltenham: Edward Elgar. 
Neffke, F., Henning, M., Boschma, R. (2011) "How do regions diversify over time? Industry relatedness and the development of new growth paths in regions", Economic Geography, 87:237-265.

O’Donoghue, D., Townshend, I. (2005) “Diversification, specialization, convergence and divergence of sectoral employment structures in the British urban system, 1991-2001", Regional Studies, 39(5):585-601.

OECD (2003) "Science, Technology and Industry Scoreboard", OECD Publishing, Paris.

Paci, R., Usai, S. (2000) "The role of specialization and diversity externalities in the agglomeration of innovative activities", Rivista Italiana Degli Economisti, 2, 237-268.

Peker, Z. (2012) "Specialization, diversity and region size", Vizyoner Dergisi, 3(6), 1-25. (in Turkish).

Rodrik, D. (2013) "Structural Change, Fundamentals, and Growth: An Overview", Institute for Advanced Study.

Romer, P.M. (1986) “Increasing Returns and Long-Run Growth".
Journal of Political Economy 94:1002-1037.

Rosenthal, S. S., Strange, W. C. (2006) "The micro-empirics of agglomeration economies", A Companion to Urban Economics, 7-23.

Siegel, P. B., Johnson, T. G., Alwang, J. (1995) "Regional economic diversity and diversification", Growth and Change, 26, 261284.

Suedekum, J. (2006) "Concentration and specialization trends in Germany since re-unification". Regional Studies, 40(8):861873.

Stimson, R. J., Stough, R. R., Roberts, B. H (2006) "Regional economic development: analysis and planning strategy", Springer, New York.

Traistaru, I., Nijkam, P., Longhi, S. (2002) "Regional specialization and concentration of industrial activity in accession countries", ZEI Working Paper, No. B16-2002.

TurkStat (2014) http://www.tuik.gov.tr/VeriBilgi.do?alt_id=1079. Accessed 1 June 2014.

\begin{tabular}{ll} 
APPENDIX (A) NUTS 2 Regions in Turkey \\
\hline TR10 & İstanbul \\
TR21 & Tekirdağ, Edirne, Kırklareli \\
TR22 & Balıkesir, Çanakkale \\
TR31 & İzmir \\
TR32 & Aydın, Denizli, Muğla \\
TR33 & Manisa, Afyon, Kütahya, Uşak \\
TR41 & Bursa, Eskişehir, Bilecik \\
TR42 & Kocaeli, Sakarya, Düzce, Bolu, Yalova \\
TR51 & Ankara \\
TR52 & Konya, Karaman \\
TR61 & Antalya, Isparta, Burdur \\
TR62 & Adana, Mersin \\
TR63 & Hatay, Kahramanmaraş, Osmaniye \\
TR71 & Kırıkkale, Aksaray, Niğde, Nevşehir, Kırşehir \\
TR72 & Kayseri, Sivas, Yozgat \\
TR81 & Zonguldak, Karabük, Bartın \\
TR82 & Kastamonu, Çankırı, Sinop \\
TR83 & Samsun, Tokat, Çorum, Amasya \\
TR90 & Trabzon, Ordu, Giresun, Rize, Artvin, Gümüşhane \\
TRA1 & Erzurum, Erzincan, Bayburt \\
TRA2 & Ağrı, Kars, lğdır, Ardahan \\
TRB1 & Malatya, Elazığ, Bingöl, Tunceli \\
TRB2 & Van, Muş, Bitlis, Hakkari \\
TRC1 & Gaziantep, Adıyaman, Kilis \\
TRC2 & Şanlıurfa, Diyarbakır \\
TRC3 & Mardin, Batman, Şırnak, Siirt \\
& \\
\hline &
\end{tabular}

\section{APPENDIX (B) NACE REV. 2 Sector codes}

10 Manufacture of food products

11 Manufacture of beverages

12 Manufacture of tobacco products

13 Manufacture of textiles

14 Manufacture of wearing apparel

15 Manufacture of leather and related products

16 Manufacture of wood and of products of wood and cork, except furniture; manufacture of articles of straw and plaiting materials

17 Manufacture of paper and paper products

18 Printing and reproduction of recorded media

19 Manufacture of coke and refined petroleum products

20 Manufacture of chemicals and chemical products

21 Manufacture of basic pharmaceutical products and pharmaceutical preparations

22 Manufacture of rubber and plastic products

23 Manufacture of other non-metallic mineral products

24 Manufacture of basic metals

25 Manufacture of fabricated metal products, except machinery and equipment

26 Manufacture of computer, electronic and optical products

27 Manufacture of electrical equipment

28 Manufacture of machinery and equipment n.e.c.

29 Manufacture of motor vehicles, trailers and semi-trailers

30 Manufacture of other transport equipment

31 Manufacture of furniture

32 Other manufacturing

33 Repair and installation of machinery and equipment 


\section{APPENDIX (C) OECD Classification of Manufacturing Industries based on Technology}

High-technology

Medium-high-technology

Medium-low-technology

Low-technology
Manufacture of basic pharmaceutical products and pharmaceutical preparations (21);

Manufacture of computer, electronic and optical products (26)

Manufacture of chemicals and chemical products (20);

Manufacture of electrical equipment (27);

Manufacture of machineryand equipment n.e.c. (28);

Manufacture of motor vehicles, trailers and semi-trailers (29);

Manufacture of other transport equipment (30)

Manufacture of coke and refined petroleum products (19);

Manufacture of rubber and plastic products (22);

Manufacture of other non-metallic mineral products (23);

Manufacture of basic metals (24);

Manufacture of fabricated metal products, except machinery and equipment (25)

Repair and installation of machinery and equipment (33)

Manufacture of food products (10);

Manufacture of beverages (11);

Manufacture of tobacco products (12);

Manufacture of textiles (13);

Manufacture of wearing apparel (14);

Manufacture of leather and related products (15);

Manufacture of wood and of products of wood and cork, except furniture; manufacture of articles of straw and plaiting materials (16);

Manufacture of paper and paper products (17);

Printing and reproduction of recorded media (18)

Manufacture of furniture (31);

Other manufacturing (32) 